\title{
Habitat structure and zonation patterns of northwestern Mediterranean shoreline strands
}

\author{
Simone Mariani ${ }^{1,2}$, Susana Pinedo ${ }^{1}$, Marc Terradas ${ }^{3}$, Maria Elena Cefalì ${ }^{1}$, \\ Eglantine Chappuis ${ }^{1}$, Enric Ballesteros ${ }^{1}$ \\ ${ }^{1}$ Centre d'Estudis Avançats de Blanes, CSIC, Accés Cala Sant Francesc 14, 17300 Blanes, Girona, Spain. \\ (SM) (Corresponding author) E-mail: mariani@ceab.csic.es. ORCID iD: http://orcid.org/0000-0003-0903-8657 \\ (SP) E-mail: pinedo@ceab.csic.es. ORCID iD: http://orcid.org/0000-0001-6431-6256 \\ (MEC) E-mail: mcefali@ceab.csic.es. ORCID iD: http://orcid.org/0000-0001-5639-0173 \\ (EC) E-mail: eglantinemaria@ @otmail.com. ORCID iD: http://orcid.org/0000-0003-1601-6683 \\ (EB) E-mail: kike@ ceab.csic.es. ORCID iD: http://orcid.org/0000-0001-5532-5337 \\ ${ }^{2}$ Departament d'Ecologia, Facultat de Biologia, Universitat de Barcelona, Avinguda Diagonal 643, \\ 08028 Barcelona, Spain. \\ ${ }^{3}$ Departamento de Ciencias del Mar y Biología Aplicada, Facultad de Ciencias, Universidad de Alicante, \\ Ap. de Correos 99, 03080, Alicante, Spain. \\ (MT) E-mail: marc.terradas@ua.es. ORCID iD: http://orcid.org/0000-0002-1916-5337
}

\begin{abstract}
Summary: We studied the habitat structure (macrofaunal assemblages and bottom types) and zonation patterns of 29 unvegetated shoreline strands along the 900-km coast of Catalonia (NW Mediterranean Sea). Organisms were sampled with grabs, pitfall traps, sticky traps, clam nets and spades to ensure capture of the different proportions of macrofaunal assemblages from the supra-, medio- and infralittoral levels. We collected 211 taxa: 194 animals and 17 algae. The most abundant and dominant organisms collected with van Veen grabs were Nematoda, Oligochaeta and Collembola at the supralittoral level; the polychaetes Saccocirrus spp. and Pisione remota, the amphipod Corophium orientale, Nematoda, and Turbellaria at the mediolittoral level; and Nematoda at the upper infralittoral level. SIMPER analysis revealed great dissimilarity between the organisms inhabiting the supralittoral and the other littoral levels. Regarding the epifauna, the sticky traps used at the supralittoral level mainly collected Collembola, which were nearly absent in pitfall traps. The qualitative study performed with a clam net and a small spade revealed that Nematoda, Saccocirrus spp., Turbellaria, Nemertea and the polychaete $P$. remota were the most abundant animals at both the medio- and the infralittoral levels and no differences were found between these levels. Different qualitative sampling methodologies showed that in fine sediments the bivalves Donax trunculus and D. semistriatus determined more than $97 \%$ of dissimilarity from coarse-sand sites. Richness increased in protected sandy and cobble shores. Littoral level and bottom-type features were only to a certain extent valid indicators of specific biotic components for a specific habitat.
\end{abstract}

Keywords: macrofauna; zonation patterns; littoral habitats; Catalonia; beach.

Estructura de los hábitats y patrones de zonación en playas del Mediterráneo noroccidental

Resumen: Se ha estudiado la estructura de los hábitats (comunidades de macrofauna y tipos de sedimento) y los patrones de zonación de 29 playas desprovistas de vegetación a lo largo de los $900 \mathrm{~km}$ de la costa de Cataluña (Mediterráneo noroccidental). El muestreo de los organismos se realizó mediante dragas, trampas de caída, trampas adhesivas, redes de marisqueo y palas para asegurar una captura exhaustiva de los organismos presentes en las comunidades de macrofauna de los niveles supralitoral, mediolitoral e infralitoral. Se colectaron 211 taxones: 194 animales y 17 algas. Los organismos más abundantes y dominantes recolectados con dragas van Veen fueron: Nematodos, Oligoquetos y Colémbolos en el nivel supralitoral; los poliquetos Saccocirrus spp. y Pisione remota, el anfípodo Corophium orientale, Nematodos y Turbelarios en el nivel mediolitoral; y Nematodos en la parte menos profunda del nivel infralitoral. Los análisis SIMPER detectaron grandes diferencias entre los organismos del nivel supralitoral y los de los otros niveles. Respecto a la epifauna, las trampas adhesivas usadas en el nivel supralitoral capturaron principalmente Colémbolos, los cuales estaban ausentes en las trampas de caida. El estudio cualitativo realizado con una red de marisqueo y una pala pequeña reveló que Nematodos, los poliquetos Saccocirrus spp. y Pisione remota, Turbelarios y Nemertinos eran los animales más abundantes tanto en el nivel mediolitoral como en el nivel infralitoral y que no había diferencias entre ambos niveles. Diferentes métodos cualitativos de muestreo revelaron que en los sedimentos finos los bivalvos Donax trunculus y D. semistriatus determinaban más del $97 \%$ de la disimilitud con los sedimentos gruesos. La riqueza en especies aumentaba en playas mixtas de arenas y cantos. El nivel y el tipo de sedimento fueron solo hasta cierto punto indicadores válidos de la composición de especies para cada hábitat concreto.

Palabras clave: macrofauna; patrones de zonación; hábitats litorales; Cataluña; playas.

Citation/Como citar este artículo: Mariani S., Pinedo S., Terradas M., Cefalì M.E., Chappuis E., Ballesteros E. 2017. Habitat structure and zonation patterns of northwestern Mediterranean shoreline strands. Sci. Mar. 81(2): 269-282. doi: http://dx.doi.org/10.3989/scimar.04445.09A 
Editor: R. Sardá.

Received: March 23, 2016. Accepted: January 18, 2017. Published: March 20, 2017.

Copyright: (C) 2017 CSIC. This is an open-access article distributed under the terms of the Creative Commons Attribution (CC-by) Spain 3.0 License.

\section{INTRODUCTION}

The distribution of habitats along rocky sea shores has been extensively studied (e.g. Underwood and Denley 1984, Menge et al. 1985, Fraschetti et al. 2005) and shows well-defined patterns of animal and plant assemblages along the vertical axis perpendicular to the shoreline (e.g. Chappuis et al. 2014, Stotz et al. 2016). Similar distributions have been described for sandy beaches (McLachlan and Jaramillo 1995, PérezDomingo et al. 2008, Reyes-Martínez et al. 2015), for which clear faunal zonation patterns along the vertical axis are acknowledged (Schlacher and Thompson 2013). On the other hand, shores characterized by the presence of coarse sediments ranging from gravels to large cobbles have been poorly studied as for habitat species compositions (but see Gauci et al. 2005). For such bottoms, the macroscopic features defining the habitats are often provided by the grain size rather than the presence of particular species or species guilds. Altogether, these systems may occupy large portions of the coastlines of many seas (Schlacher and Thompson 2013). Nonetheless, as other authors have long pointed out, these environments, often regarded as marine deserts (see McLachlan 1983), are among the least known because of their biodiversity and the functioning of their communities.

Shoreline strands, and notably sandy beaches, are also well-known for their ecological importance, for the special adaptations of their fauna and flora, and for the tremendous impacts of human activities and natural disturbances (Węslawski et al. 2000, McLachlan and Brown 2006, Bessa et al. 2013). In spite of the existence of several seminal reports (Dahl 1952, McLachlan 1983) and other similar studies from other seas (e.g. Janssen and Mulder 2005, Rodil et al. 2006, Rodil et al. 2014), most research on the macroinvertebrate fauna from shoreline strands of the Mediterranean Sea has focussed on the organisms inhabiting lower infralittoral habitats (Pinedo et al. 1997, Sardá et al. 1999, Labrune et al. 2007). To date, there are a few comprehensive accounts in the literature about the macroinvertebrates from Mediterranean Sea shoreline strands and beaches in general (Deidun et al. 2003, Colombini et al. 2003, Gauci et al. 2005). Mediterranean shoreline strands are inhabited by animals ranging from tiny Collembola and flying insects to large bivalves and crustaceans (Marques et al. 2003, Colombini et al. 2005, Covazzi Harriague and Albertelli 2007). However, very little information is available for the northwestern Mediterranean Sea, where research has only been conducted on small swimming animals, mainly crustaceans (Munilla and San Vicente 2005).

In the last few decades of the twentieth century, the focus of conservation shifted unmistakably from species to habitats. In Europe, the Habitats Directive (92/43/EEC) states that the habitat of a species is an environment defined by specific abiotic and biotic factors, in which the species lives at any stage of its biological cycle.

Many habitat classification schemes often use the classical division of the littoral into three main levels: supra-, medio- and infralittoral. For example, while the European Nature Information System (EUNIS) considers these divisions in some instances (e.g. A.2.25, Mediterranean communities of mediolittoral sands), in other cases the nomenclature does not specify the littoral level to which a habitat is assigned (e.g. A2.11 Shingle (pebble) and gravel shores). Other classification schemes for the Mediterranean Sea adopt these divisions. In the Lista Patrón de los Hábitats Marinos Presentes en España" (hereafter LPRE, Templado et al. 2012), and to a lesser extent in the original Coordination of the Information of the Environment (CORINE) Biotopes, each habitat is framed within the corresponding littoral level.

The main goal of this study was to characterize sediment grain features and macrofaunal assemblages from 29 unvegetated shoreline strands along the whole coast of Catalonia (NW Mediterranean Sea). The study represents the first descriptive assessment of the zonation patterns of the organisms found from the upper supralittoral level down to the upper infralittoral level (one metre depth). By relating taxon presence and abundance to granulometric features of the strands, we also evaluate whether the EUNIS, CORINE Biotopes (Ballesteros et al. 2014) and LPRE (Templado et al. 2012) habitat classifications, which are based on sediment composition and shore levels, reflect actual differences in species distributions for the area studied.

\section{MATERIALS AND METHODS}

\section{Sampling}

To avoid the presence of people and beach-cleaning machines, which operate mainly in summer, 29 shoreline strands (Fig. 1) were visited between autumn and winter either in 2010 or 2011. To study habitat structure and species composition, sediment samples for granulometric and biological analysis were collected at each site and for each level (supra-, medio- and upper infralittoral, see Fig. 2).

The sediment was stored in $250-\mathrm{mL}$ plastic pots and taken to the laboratory. Most samples were analysed by sieving the dry sediment through a 2000, 1000, 750, $500,375,250,125$ and $63 \mu \mathrm{m}$ column of mesh sizes. When very fine grains were found, the samples were analysed using an automatic Mastersizer 2000 (Malvern instruments Ltd., UK). 


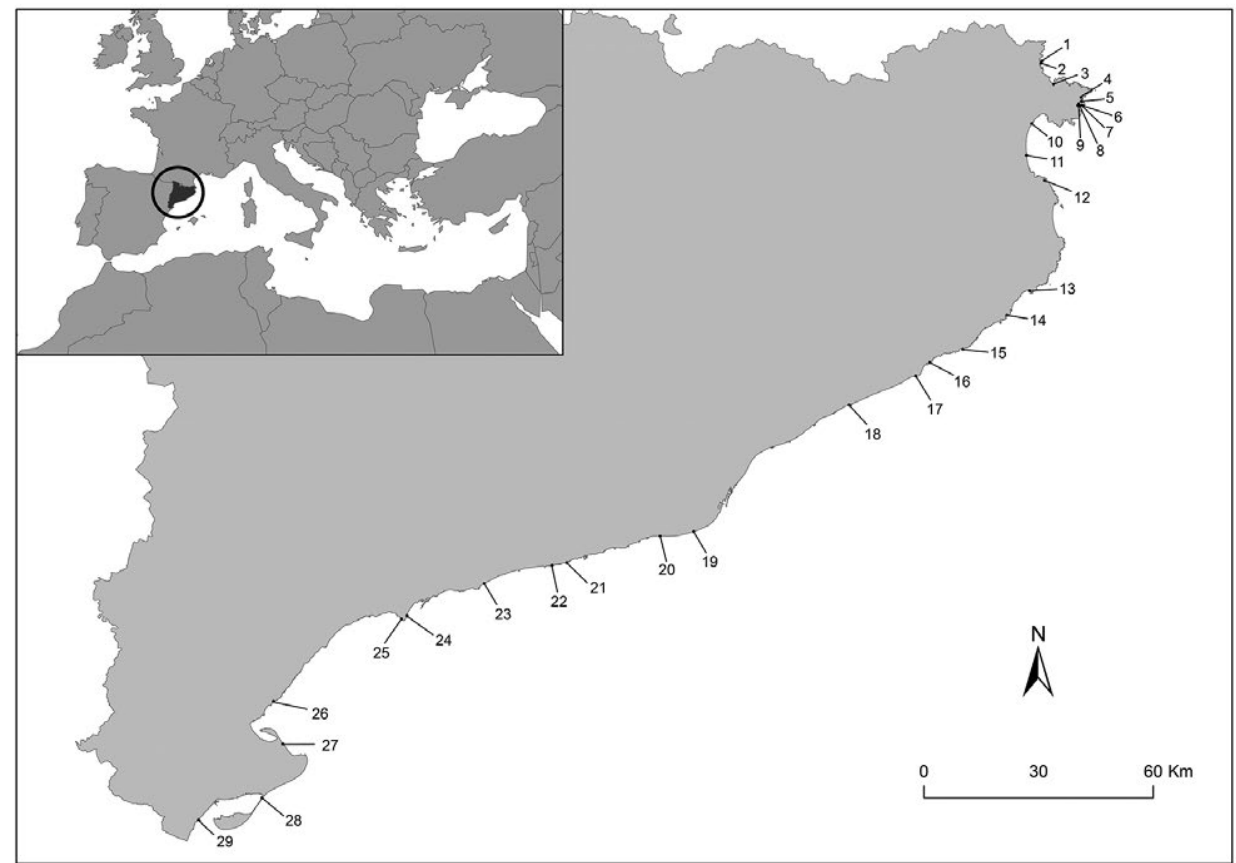

Fig. 1. - Map of the studied coastline. The position of each site is shown (see Tables 1 and 2 for details).
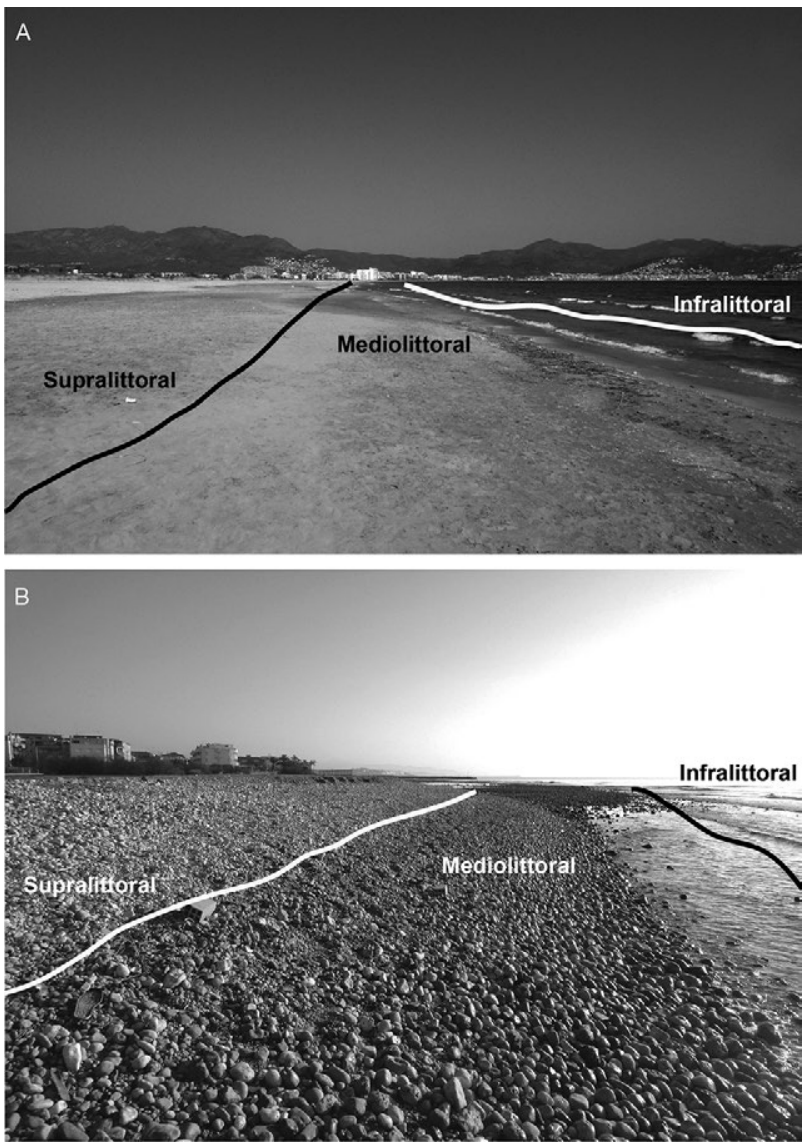

Fig. 2. - The three littoral levels on a sand-dominated (A) and a cobble-dominated (B) strand.

To obtain the most representative organisms characterizing the habitats, samplings were carried out using different devices at 29 sites (Fig. 1). We selected 19 sites as representative of different grain sizes and gen- eral strand morphology to sample the infauna at each level using a van Veen grab of $600 \mathrm{~cm}^{2}$ area (Table 1). At each site, one single grab was used at each littoral level. The van Veen grab is a widely used device and was used in order to facilitate comparison of our data with those from other studies.

To collect the organisms that move over the shore sediment at the supralittoral level (epifauna), pitfall traps and sticky traps were used. Pitfall traps were made of 500-mL plastic pots filled with tap water and a few drops of formaldehyde. Each trap was inserted into the sediment so that the pot mouth was flush with the strand surface. At one side of the pitfall trap, a $66 \times 4.5 \mathrm{~cm}$ sticky trap was installed. Both devices were left at dusk and collected the next morning. For several reasons (e.g. broken, missing or flooded traps), data were not available for all the 19 sites (see details in Table 1).

The van Veen grab sampling area of $600 \mathrm{~cm}^{2}$ is too small for a representative sampling of large molluscs. To ensure their collection, a clam net $(30 \times 15$ $\mathrm{cm}$ mouth, $0.7 \mathrm{~cm}$ mesh size) was used in the medio- and the upper infralittoral levels at nine sites for which previous knowledge about past presence of bivalves existed (Table 1). The clam net was trawled once along an approximately 20-m-long transect parallel to the shore at each site and for each littoral level (see Table 1 for details). A tiny spade $(30 \mathrm{~cm}$ long, 7 wide) was also used to sample sediments where the clam net was difficult to handle (e.g. around stones). At one particular site on the Ebre River Delta outer beach (site 27, Marquesa Beach) medio- and infralittoral habitats were represented by compacted clays. Since the use of the grab was practically impossible, sampling was done with the tiny spade. At that site, the medio- and infralittoral levels, which were hardly distinguishable, were sampled through a single sedi- 
Table 1. - The different methods employed at each site to sample the three littoral levels.

\begin{tabular}{|c|c|c|c|}
\hline & supralittoral & mediolittoral & infralittoral \\
\hline 1 Borró Gran & grab, pitfall trap, sticky trap & grab & grab \\
\hline 2 Canyelles & pitfall trap, spade (wrack) & - & - \\
\hline 3 Port de la Selva & grab, pitfall trap, sticky trap, spade (wrack) & grab, spade & grab \\
\hline 4 Jonquet & - & - & spade \\
\hline 5 Portlligat & grab & grab & grab, clam net, spade \\
\hline 6 Confitera & - & clam net, spade & clam net, spade \\
\hline 7 Ros & - & clam net, spade & clam net, spade \\
\hline 8 Llaner & - & clam net, spade & clam net, spade \\
\hline 9 Empuriabrava & grab, pitfall trap, sticky trap & grab & grab \\
\hline 10 Sant Pere Pescador & grab, pitfall trap, sticky trap & grab & grab \\
\hline 11 Montgó & grab, pitfall trap, sticky trap & grab & grab \\
\hline 12 Palamós & - & clam net, spade & clam net, spade \\
\hline 13 Sant Pol & grab, pitfall trap, sticky trap & grab & grab \\
\hline 14 Sant Feliu & - & clam net, spade & clam net, spade \\
\hline 15 Llevador & grab, pitfall trap, sticky trap & grab & grab \\
\hline 16 Sant Francesc & grab & grab & grab \\
\hline 17 Malgrat & grab, pitfall trap, sticky trap & grab & grab \\
\hline 18 Arenys de Mar & grab, pitfall trap, sticky trap & grab & grab \\
\hline 19 Remolar & grab, pitfall trap, sticky trap & grab & grab \\
\hline 20 Castelldefels & grab & clam net, spade & clam net, spade \\
\hline 21 Delta del Foix & grab, pitfall trap, sticky trap & grab & grab \\
\hline 22 Cubelles & - & clam net, spade & clam net, spade \\
\hline 23 Torredembarra & grab, pitfall trap, sticky trap & grab & grab \\
\hline 24 Pineda & spade & clam net, spade & clam net, spade \\
\hline 25 Cala Font & grab, pitfall trap, sticky trap & grab & grab \\
\hline 26 Estany Podrit & grab, pitfall trap, sticky trap & grab & grab \\
\hline 27 Marquesa & - & spade & spade \\
\hline 28 Aluet & grab, pitfall trap, sticky trap & grab & grab \\
\hline 29 Martinenca & grab, pitfall trap, sticky trap & grab & grab \\
\hline
\end{tabular}

Table 2. - The different substrate types found at each site for the three littoral levels.

\begin{tabular}{|c|c|c|c|}
\hline & supralittoral & mediolittoral & infralittoral \\
\hline 1 Borró Gran & cobbles, gravels, and sand & gravels, cobbles, and sand & gravels and sand \\
\hline 2 Canyelles & P. oceanica wracks & - & - \\
\hline 3 Port de la Selva & $\begin{array}{c}\text { cobbles, gravels, and } P \text {. oceanica } \\
\text { wracks }\end{array}$ & $\begin{array}{c}\text { coarse sands, gravels, and } P . \text { oceanica } \\
\text { wracks }\end{array}$ & cobbles and gravels \\
\hline 4 Jonquet & - & - & cobbles, gravels, and $C$. nodosa \\
\hline 5 Portlligat & cobbles and fine sands & coarse sands and gravels & cobbles \\
\hline 6 Confitera & - & cobbles and gravels & cobbles and gravels \\
\hline 7 Ros & - & coarse sands and gravels & cobbles and gravels \\
\hline 8 Llaner & - & coarse sands and gravels & cobbles and gravels \\
\hline 9 Empuriabrava & gravels & coarse sands and gravels & cobbles, gravels, and coarse sands \\
\hline 10 Sant Pere Pescador & medium sands & gravels and very coarse sands & medium sands \\
\hline 11 Montgó & cobbles and gravels & gravels and cobbles & cobbles and gravels \\
\hline 12 Palamós & - & gravels & gravels and very coarse sands \\
\hline 13 Sant Pol & gravels & gravels and very coarse sands & medium sands \\
\hline 14 Sant Feliu & - & very coarse sands and gravels & very coarse sands and gravels \\
\hline 15 Llevador & cobbles & cobbles & large cobbles \\
\hline 16 Sant Francesc & very coarse sands and gravels & very coarse sands and gravels & very coarse sands and gravels \\
\hline 17 Malgrat & gravels & gravels and cobbles & cobbles and gravels \\
\hline 18 Arenys de Mar & gravels and cobbles & very coarse sands and gravels & gravels and cobbles \\
\hline 19 Remolar & medium and fine sands & medium sands & fine sands \\
\hline 20 Castelldefels & fine and medium sands & medium sands & fine sands \\
\hline 21 Delta del Foix & cobbles and gravels & gravels and cobbles & large cobbles \\
\hline 22 Cubelles & - & fine sands & fine sands \\
\hline 23 Torredembarra & fine sands & fine and medium sands & fine sands \\
\hline 24 Pineda & fine sands & fine sands & fine sands \\
\hline 25 Cala Font & fine sands & fine sands & fine sands \\
\hline 26 Estany Podrit & cobbles and gravels & cobbles and gravels & fine sands \\
\hline 27 Marquesa & - & compacted clays & compacted clays \\
\hline 28 Aluet & fine sands & fine and medium sands & fine sands \\
\hline 29 Martinenca & fine sands & fine and medium sands & fine and medium sands \\
\hline
\end{tabular}

ment collection. The sample volume was comparable to that collected for the other sediment types. The spade was also used at Jonquet (site 4) to sample the infralittoral sediment around Cymodocea nodosa sheaths and to collect Posidonia oceanica wracks at the supralittoral level of two sites: Canyelles (site 2) and Port de la Selva (site 3, Table 1).

All samples were stored in sealed plastic bags with a formalin-seawater solution and taken to the labora- tory for sorting and identification of the organisms under the dissecting microscope.

Quantitative data were obtained from the grab, pitfall and sticky trap methodologies. Samples taken with both the net and the spade were qualitatively analysed. The presence of seagrass and seaweeds was also recorded. The sampling tools employed at each study site are detailed in Table 1. 
Table 3. - Codes used for the sediment description in the analyses and figures. Only dominant proportions are shown.

\begin{tabular}{ll}
\hline Code & Sediment description \\
\hline C & Large to small cobbles and cobbles with sands \\
CG & Cobbles and gravels \\
G & Gravels and gravels with sands \\
CoSG & Coarse to very coarse sands and gravels \\
MeS & Medium sands alone or with fine sands \\
FiS & Fine sands alone or with medium sands \\
CC & Compacted clays \\
PO & Posidonia oceanica wracks \\
\hline
\end{tabular}

\section{Data treatment and statistical analysis}

Quantitative and qualitative data were analysed separately. Abundance data resulting from grabs (ind $\mathrm{m}^{-2}$ ) and traps (standardized to individuals per hour per trap) were square root transformed for further analysis. All organisms collected with the spade or the clam net were analysed based on their presence or absence in the samples. Non-metric multidimensional scaling (MDS) ordinations based on taxa composition (Bray-Curtis similarity, average link grouping) were done to identify patterns of similarities among sites. An analysis of similarities (ANOSIM) was used to test the differences between groups of samples. Finally, the similarity/ dissimilarity percentages analysis (SIMPER) was performed in order to identify the species characterizing each level or group of samples.

PRIMER v6 software with PERMANOVA add-on was used to run the analyses.

\section{RESULTS}

The granulometry of the studied shoreline strands ranged from fine sands to large cobbles (Table 2). The sediment type often changed throughout the three shore levels (supra-, medio- and infralittoral). P. oceanica wracks (two sites), $C$. nodosa meadows (one site), and compacted clays (one site) were also found (Table 2). Sediment codes used in the analyses and relative figures (see below) and in the Supplementary Material are listed in Table 3.
We distinguished five different habitats at the supralittoral, six at the mediolittoral, and seven at the infralittoral level by their substrate characteristics (see Appendix). These habitats corresponded to different extents to habitats from the LPRE, EUNIS, and CORINE Biotopes nomenclatures (Appendix 1). Correspondences with habitat codes from the three classifications and with the main taxa found in each of the sampled habitats are detailed in the Appendix 1.

Grabs, traps and clam nets allowed us to collect a wide proportion of the organisms inhabiting the strands. A total of 211 taxa were collected, most of them animals (194; Supplementary Material, Table S1) but also some algae (17).

In the supralittoral level, Nematoda and Oligochaeta were the most abundant and frequent taxa collected with the grabs (Table 4). Springtails (Collembola) were the most abundant and dominant organisms in the sticky traps, except at most fine-sand sites, where few organisms were collected with this method (see Supplementary Material, Table S1). Pitfall traps captured few specimens, of which the Collembola and the amphipods Talitrus saltator and Cryptorchestia cavimana were the most abundant ones (Supplementary Material, Table S1). At the mediolittoral level, polychaetes of the genus Saccocirrus were the most abundant organisms captured with the grabs (Table 5), mainly in coarse sediments, followed by the amphipod Corophium orientale, Nematoda, Turbellaria, and the polychaete Pisione remota (Table 5). At the infralittoral level, Nematoda were overall the most abundant animals, but Saccocirrus spp. were the most frequent organisms at most northern sites with coarse sediments (Table 5). Some taxa were irregularly very abundant: Polychaetes (Ctenodrilus serratus, Eurydice affinis, Malacoceros fuliginosus, Notomastus latericeus and Salvatoria spp.), amphipods (Hyale perieri and Melita spp.) and the gastropod Neverita josephinia (Table 5).

The qualitative samplings carried out with the clam net and the spade at the medio- and infralittoral levels allowed us to collect some bivalves species that were absent in the samples collected with the grabs. The

Table 4. - Main taxa collected at the supralittoral level with the grab method. Taxa are ordered by their total abundance (ind $\mathrm{m}^{-2}$ ). Only taxa representing up to $70 \%$ of the total abundance at each site are included. See Tables 1 and 2 for site numbers. Asterisks indicate widespread taxa that are not included in the $70 \%$ of the total abundance at a particular site.

\begin{tabular}{|c|c|c|c|c|c|c|c|c|c|c|c|c|c|c|c|c|c|c|c|}
\hline & 1 & 3 & 5 & 9 & 10 & 11 & 13 & 15 & 16 & 17 & 18 & 19 & 20 & 21 & 23 & 25 & 26 & 28 & 29 \\
\hline Nematoda & & & 32 & & & $*$ & & & & & & & 5 & & & & & 3200 & $*$ \\
\hline Corophium orientale & & & & & & & & & & & & & & & & & & 800 & \\
\hline Oligochaeta & & 144 & 64 & 4 & & 28 & 67 & & & 46 & & & & $*$ & & & & $*$ & \\
\hline Turbellaria & & & & & & & & & & & & & & 283 & & & & & \\
\hline Collembola & & $*$ & & & & & & 33 & 8 & & 67 & & & & & & & & \\
\hline Antalis cf. vulgaris & & & & & & & & & & & 133 & & & & & & & & \\
\hline Siphonoecetes dellavallei & & & & & & & & & & & & & & & 67 & & & & \\
\hline Staphylinidae & & & & 8 & & & $*$ & & & & & & & & & & & & \\
\hline Leptochelia savignyi & & & & & 4 & $*$ & & & & & & & & $*$ & & & & & \\
\hline Coleoptera sp1 & & & & 4 & & & & & & & & & & $*$ & & & & & \\
\hline Formicidae & & & & 8 & & 8 & & & & & & & & & & & & & \\
\hline Apocrita & & & & & 4 & 8 & & & & & & & & & & & & & \\
\hline Diptera sp. 7 & & & & & & & & & & & & & & & & & & & 8 \\
\hline Labidura riparia & & & & & & 8 & & & & & & & & & & & & & \\
\hline Aora gracilis & & & & & & 8 & & & & & & & & & & & & & \\
\hline Platynereis sp. & & & & & 8 & & & & & & & & & & & & & & \\
\hline Ampithoe cf. spuria & & & & & & & & & 4 & & & & & & & & & & \\
\hline Abundance & 0 & 180 & 96 & 32 & 20 & 84 & 83 & 33 & 16 & 50 & 216 & 0 & 6 & 367 & 83 & 0 & 0 & 4684 & 12 \\
\hline Richness & 0 & 3 & 2 & 6 & 4 & 11 & 2 & 1 & 3 & 2 & 3 & 0 & 2 & 6 & 2 & 0 & 0 & 13 & 2 \\
\hline
\end{tabular}


274 • S. Mariani et al.

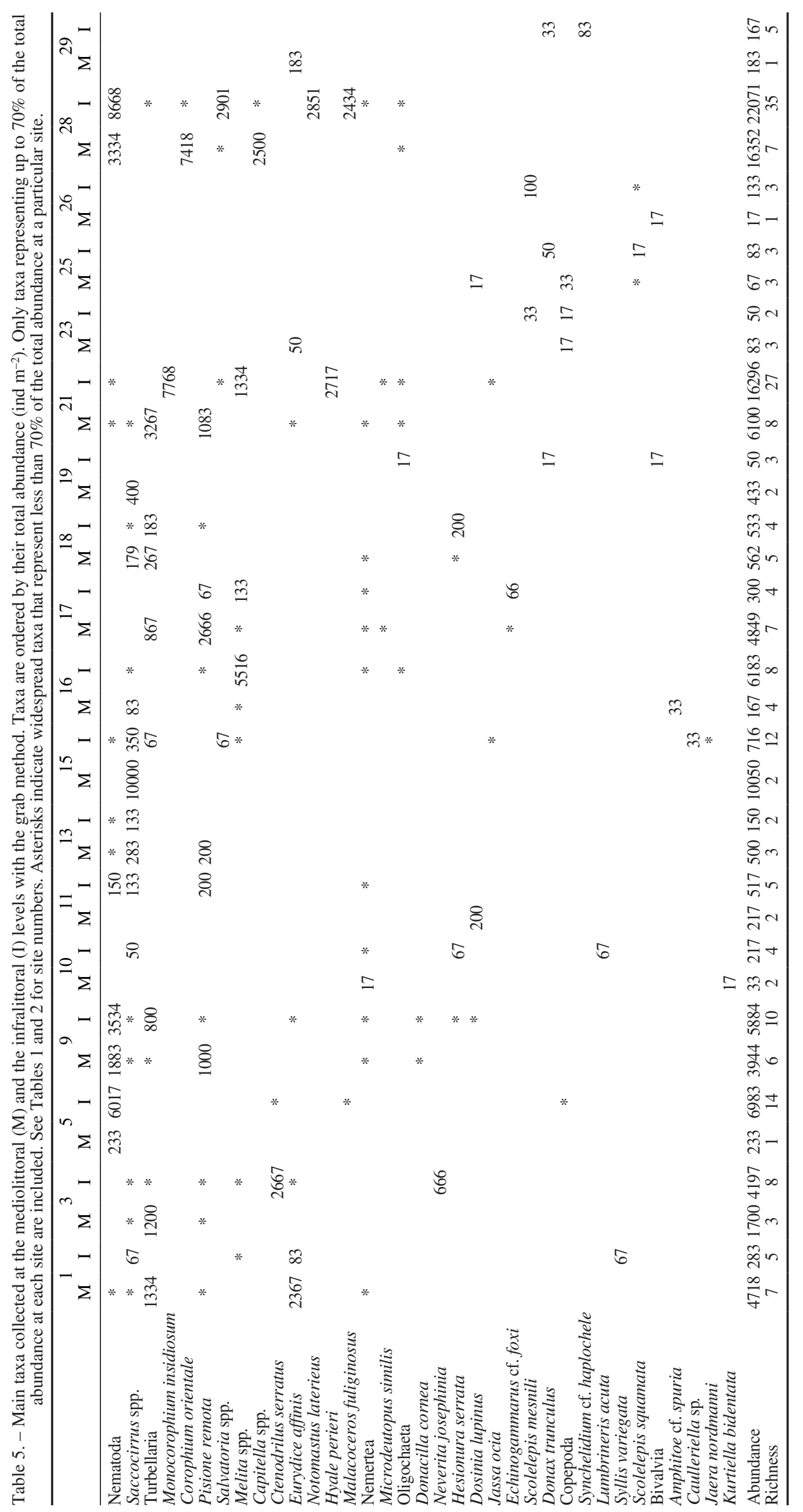

SCI. MAR. 81(2), June 2017, 269-282. ISSN-L 0214-8358 doi: http://dx.doi.org/10.3989/scimar.04445.09A 
Table 6. - Main taxa collected through the qualitative sampling at the supralittoral (S), mediolittoral (M) and infralittoral (I) levels. Taxa are ordered by their total frequency throughout sites. Only taxa found at more than one site are shown. For the site numbers see Tables 1 and 2.

\begin{tabular}{|c|c|c|c|c|c|c|c|c|c|c|c|c|c|c|c|c|c|c|c|c|c|c|c|}
\hline & \multirow{2}{*}{$\begin{array}{l}2 \\
\mathrm{~S}\end{array}$} & \multicolumn{2}{|c|}{3} & \multirow{2}{*}{$\begin{array}{l}4 \\
\mathrm{I}\end{array}$} & \multirow{2}{*}{$\begin{array}{l}5 \\
\mathrm{I}\end{array}$} & \multicolumn{2}{|c|}{6} & \multicolumn{2}{|c|}{7} & \multicolumn{2}{|c|}{8} & \multicolumn{2}{|c|}{12} & \multicolumn{2}{|c|}{14} & \multicolumn{2}{|c|}{20} & \multicolumn{2}{|c|}{22} & \multicolumn{3}{|c|}{24} & \multirow{2}{*}{$\begin{array}{c}27 \\
\text { M-I }\end{array}$} \\
\hline & & S & M & & & M & $\mathrm{I}$ & M & $\mathrm{I}$ & M & I & M & $\mathrm{I}$ & M & I & M & $\mathrm{I}$ & M & $\mathrm{I}$ & $\mathrm{S}$ & M & I & \\
\hline Nematoda & & & & + & & + & & + & & + & & + & + & + & + & & & & & & & & \\
\hline Saccocirrus & & & & & & + & & & + & & + & + & + & + & + & + & & & & & & & \\
\hline Turbellaria & + & & + & + & & & + & & + & + & & & + & + & & & & & & & & & \\
\hline Nemertea & & & & & & & & + & & & + & + & + & + & & & & & + & & & & \\
\hline Pisione remota & & & & & & & & & & + & + & + & + & + & + & & & & & & & & \\
\hline Oligochaeta & & & & & & & & + & & + & + & & & + & + & & & & & & & & \\
\hline Donax trunculus & & & & & & & & & & & & & & & & & + & + & & & + & + & \\
\hline Portumnus latipes & & & & & & & + & & & & & & & & & & + & & & & + & + & \\
\hline Donax semistriatus & & & & & & & & & & & & & & & & & & + & & & + & + & \\
\hline Nereididae & + & & & + & & & & & & & + & & & & & & & & & & & & \\
\hline Scolelepis squamata & & & & & & & & & & & & & & & & & & & + & & + & + & \\
\hline Capitella spp. & & & & & & & + & & & & & & & & & & & & & + & & & \\
\hline Carcinus aestuarii & & & & & + & & + & & & & & & & & & & & & & & & & \\
\hline Cerastoderma glaucum & & & & & + & & & & & & & & & & & & & & + & & & & \\
\hline Ensis minor & & & & & & & & & & & & & & & & & & & & & + & + & \\
\hline Eurydice affinis & & & & & & & & & & & & & & & & + & & & & + & & & \\
\hline Hesionura serrata & & & & & & & & & & & & + & & + & & & & & & & & & \\
\hline Naineris laevigata & & & & + & & & & & & & & & & & & & + & & & & & & \\
\hline Nassarius mutabilis & & & & & & & & & & & & & & & & & & + & + & & & & \\
\hline Protodrillus sp. & & & & & & & & & + & & & & + & & & & & & & & & & \\
\hline Siphonoecetes dellavallei & & & & & & & & & & & & & & & & & & & & + & & & + \\
\hline Richness & 9 & 1 & 1 & 24 & 2 & 2 & 6 & 3 & 3 & 4 & 9 & 5 & 6 & 10 & 4 & 2 & 6 & 3 & 7 & 4 & 5 & 9 & 6 \\
\hline
\end{tabular}

Table 7. - Contributions and average abundances of species responsible for $70 \%$ of dissimilarities (SIMPER analysis) between groups (supralittoral (S), mediolittoral (M), and infralittoral (I) levels) based on total macrofaunal composition. Total dissimilarity between groups is

\begin{tabular}{|c|c|c|c|c|c|}
\hline & Taxa & Average abundance & Average abundance & Contribution $(\%)$ & Cumulative contribution $(\%)$ \\
\hline \multirow[t]{14}{*}{ Groups M and I (89.20\%) } & & Group M & Group I & & \\
\hline & Saccocirrus spp. & 11.51 & 6.38 & 13.93 & 13.93 \\
\hline & Nematoda & 9.84 & 14.80 & 11.59 & 25.52 \\
\hline & Turbelaria & 10.13 & 3.64 & 8.50 & 34.03 \\
\hline & Pisione remota & 8.98 & 3.94 & 8.16 & 42.19 \\
\hline & Eurydice affinis & 4.24 & 1.37 & 5.69 & 47.88 \\
\hline & Nemertea & 4.55 & 2.45 & 4.65 & 52.53 \\
\hline & Scolelepis mesnili & 0 & 0.88 & 2.89 & 55.42 \\
\hline & Dosinia lupinus & 1.01 & 0.45 & 2.70 & 58.12 \\
\hline & Donax trunculus & 0 & 0.94 & 2.68 & 60.80 \\
\hline & Melita bulla & 1.32 & 1.98 & 2.67 & 63.47 \\
\hline & Hesionura serrata & 0.32 & 1.69 & 2.62 & 66.10 \\
\hline & Melita palmata & 0 & 4.36 & 2.43 & 68.53 \\
\hline & Ctenodrilus serratus & 0 & 3.72 & 2.10 & 70.63 \\
\hline \multirow{9}{*}{ Groups $\mathrm{M}$ and $\mathrm{S}(97.73 \%)$} & & Group M & Group S & & \\
\hline & Saccocirrus spp. & 11.51 & 0 & 15.01 & 15.01 \\
\hline & Nematoda & 9.84 & 4.89 & 12.09 & 27.09 \\
\hline & Turbelaria & 10.13 & 1.20 & 9.71 & 36.81 \\
\hline & Oligochaeta & 0.62 & 3.45 & 8.42 & 45.23 \\
\hline & Pisione remota & 8.98 & 0 & 7.90 & 53.12 \\
\hline & Eurydice affinis & 4.24 & 0 & 7.55 & 60.67 \\
\hline & Nemertea & 4.55 & 0 & 4.88 & 65.55 \\
\hline & Dosinia lupinus & 1.01 & 0 & 4.49 & 70.04 \\
\hline \multirow[t]{17}{*}{ Groups I and S (97.09 \%) } & & Group I & Group S & & \\
\hline & Nematoda & 14.80 & 4.89 & 11.00 & 11.00 \\
\hline & Saccocirrus spp. & 6.38 & 0 & 10.57 & 21.57 \\
\hline & Oligochaeta & 2.36 & 3.45 & 7.62 & 29.18 \\
\hline & Turbelaria & 3.64 & 1.20 & 4.88 & 34.06 \\
\hline & Scolelepis mesnili & 0.88 & 0.25 & 4.56 & 38.63 \\
\hline & Pisione remota & 3.94 & 0 & 4.18 & 42.81 \\
\hline & Donax trunculus & 0.94 & 0 & 3.98 & 46.79 \\
\hline & Collembola & 0 & 1.60 & 3.61 & 50.39 \\
\hline & Hesionura serrata & 1.69 & 0 & 3.09 & 53.49 \\
\hline & Melita palmata & 4.36 & 0 & 2.86 & 56.35 \\
\hline & Nemertea & 2.45 & 0 & 2.73 & 59.08 \\
\hline & Melita bulla & 1.98 & 0 & 2.61 & 61.69 \\
\hline & Ctenodrilus serratus & 3.72 & 0 & 2.31 & 64.00 \\
\hline & Melita valesi & 3.64 & 0 & 2.26 & 66.26 \\
\hline & Scolelepis squamata & 0.45 & 0 & 2.02 & 68.28 \\
\hline & Eurydice affinis & 1.37 & 0 & 1.96 & 70.24 \\
\hline
\end{tabular}

bivalves Donax semistriatus, D. trunculus and Ensis minor were exclusively present at the southern sites (Table 6). Nematoda, Saccocirrus spp. Turbellaria,
Nemertea and the polychaete $P$. remota were the organisms most frequently collected (Table 6) through the qualitative sampling. The maximum numbers of 

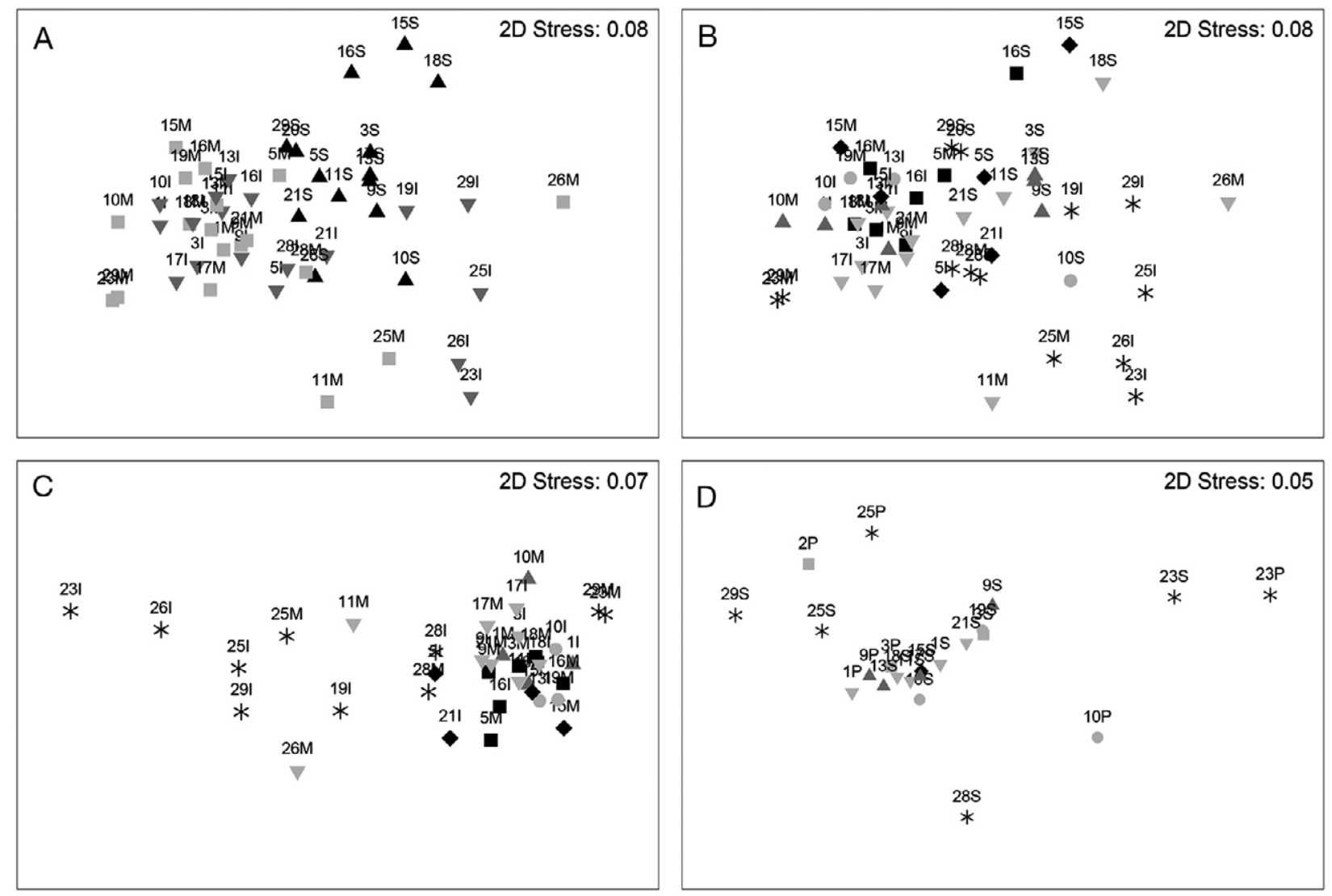

Fig. 3. - MDS plots. A, plot based on macrofauna abundance (ind $\mathrm{m}^{-2}$ ) of grab samples showing the littoral level: S, supralittoral, dark triangle; M, mediolittoral, quadrat; I, infralittoral, bright triangle. B, plot based on macrofauna abundance (ind $\mathrm{m}^{-2}$ ) of grab samples showing the sediment type. C, plot based on macrofauna abundance (ind $\mathrm{m}^{-2}$ ) of the medio- and infralittoral grab samples showing the sediment type. D, plot based on macrofauna collected with traps in the supralittoral, with label indicating the sampling method (P, pitfall; $\mathrm{S}$, sticky). Labels indicate the site number and the littoral level in plots A, B and C. Sediment types (see Table 3 for codes) are plotted as follows: C, rhombus; CG, bright triangle; G, dark triangle; CoSG, quadrat; MeS, circle; FiS, asterisk; PO, quadrat.

taxa (24) were found at the infralittoral level of the shallow meadow of $C$. nodosa (site 4, Table 2 and Supplementary Material, Table S1) and 20 of them were exclusively present at this site. The isopod Sphaeroma serratum was exclusively present at Marquesa (site 27, see Supplementary Material, Table S1) and represented a new finding for the Iberian Peninsula.

Erect algae covered the upper surface of the large cobbles of Llevador (site 15) and Delta del Foix (site 21). The green algae Chaetomorpha mediterranea and Cladophora spp., the red algae Polysiphonia tripinnata and Ceramium diaphanum, and the brown alga Dictyota sp. were found at Llevador. Cobbles from Delta del Foix were colonized by the red algae Gelidium pusillum, Haliptilon virgatum, Ceramium gr. strictum, Polysiphonia sertularioides and Corallina elongata and the green alga Cladophora albida. The presence of algae was also observed in the infralittoral fine sands of Aluet (site 28), where the red alga Chondria capillaris and the green alga Ulva curvata were present. The xanthophyte Vaucheria submarina was collected in Cubelles (site 22). Finally, several algae were collected over the compacted clays of Marquesa beach (site 27): the green algae Cladophora vagabunda and Ulva prolifera and the red algae $C$. diaphanum and Polysiphonia sp.
The MDS analysis with the data collected with the grabs showed that only the supralittoral segregated from the other two levels, which were highly overlapped (Fig. 3A). The ANOSIM test showed that the supralittoral level was significantly different from the medio- and infralittoral levels $(\mathrm{p}<0.001)$, but no significant differences were found between these two levels ( $p>0.05)$. SIMPER analysis revealed that the average dissimilarity was more than $97 \%$ between the organisms inhabiting the supralittoral and those of the medio- and infralittoral levels (Table 7). The presence of Oligochaeta at the supralittoral level and Saccocirrus spp. and Nematoda at the medio- and infralittoral levels determined the dissimilarities between levels. As for the distribution of granulometry across the samples (Fig. 3B), most bottom types were mixed up together (ANOSIM; $p>0.05$ ), although fine sands were slightly segregated at the MDS plot. The dissimilarity of fine-sand assemblages from the rest of sediment types was more than 96\% (SIMPER analysis). $P$. remota, Saccocirrus spp. and Turbellaria, which strongly characterized medium to large grain-sized strands at the medio- and infralittoral levels, were in fact negligible in fine sands, where Nematoda, Scolelepis squamata, S. mesnili, D. trunculus and E. affinis dominated. 


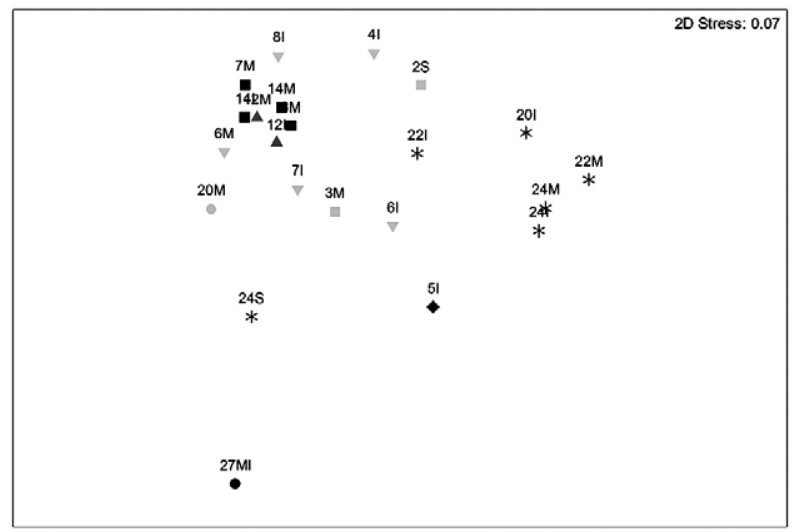

Fig. 4. - MDS plot based on qualitative samples. Labels include the site number (see Table 1) and the littoral level (S, supralittoral; M, mediolittoral; I, infralittoral). Sediment types (see Table 3 for codes) are plotted as follows: $\mathrm{C}$, rhombus; $\mathrm{CG}$, bright triangle; $\mathrm{G}$, dark triangle; CoSG, dark quadrat; MeS, bright circle; FiS, asterisk; $\mathrm{CC}$, dark circle; $\mathrm{PO}$, bright quadrat.

Although medio- and infralittoral samples plotted together when supralittoral samples were excluded from the analyses (Fig. 3C), the infralittoral level of sites 19, $23,25,26$, and 29 and the mediolittoral level of sites 11,25 and 26 were segregated. The markedly different position was mainly due to the presence of the abovementioned taxa, which were exclusive of fine sands, and the lack of those characteristic of coarse sediments.

The MDS analyses performed with the supralittoral epifauna captured with traps revealed no clear pattern (Fig. 3D) for either the sample device used (pitfall and sticky traps; ANOSIM, p>0.05) or the bottom type (ANOSIM, $p>0.05$ ). However, fine-sand sediments plotted separated from the other bottom types. SIMPER analysis revealed more than $93 \%$ dissimilarity between fine-sand assemblages and the other assemblages. Pairwise tests showed a significant difference $(\mathrm{p}<0.05$, $\mathrm{R}=0.325$ ) between the assemblages of macroinvertebrates inhabiting cobbles and gravels and those found in fine sands. When fine sands were removed from the analyses, the sampling methods (sticky and pitfall traps) were clearly separated (ANOSIM, R=0.420, $\mathrm{p}<0.05)$. Sticky traps mainly collected Collembola, which were almost absent in pitfall traps. The species $T$. saltator was exclusively found in pitfall traps.

The MDS analyses performed with the qualitative samples (Fig. 4) showed noticeable and significant dissimilarities between substrate types (ANOSIM, $\mathrm{R}=0.443, \mathrm{p}<0.05)$. Fine sands plotted separately from the rest of bottom types (Fig. 4). The presence of the bivalves $D$. trunculus and $D$. semistriatus at the fine-sand sites accounted for more than $97 \%$ of the dissimilarity (SIMPER analysis) between these sites and those with $P$. oceanica wracks $(\mathrm{R}=0.625, \mathrm{p}<0.05)$, cobbles and gravels $(\mathrm{R}=0.528, \mathrm{p}<0.01)$, coarse to very coarse sand and gravels $(\mathrm{R}=0.681, \mathrm{p}<0.01)$, and those dominated by gravels $(\mathrm{R}=0.536, \mathrm{p}<0.05)$. The high dissimilarities observed were mainly due to the presence of Turbellaria in $P$. oceanica wracks, cobbles and gravels, to the presence of Saccocirrus spp. in cobble and gravel bottoms, and to the presence of Nematoda, Oligochaeta and the species $P$. remota at sites dominated by coarse to very coarse sand and gravels. Those species were never recorded in the qualitative samples from sites dominated by fine sands. Finally, qualitative samples showed no clear pattern as regards the littoral levels (ANOSIM, $\mathrm{p}>0.05$ ).

\section{DISCUSSION}

With the exception of the studies of Munilla et al. (1998) and Munilla and San Vicente (2005) on suprabenthos of Catalan beaches and several studies focussing on a few macrobenthic taxa from vegetated sandy littoral ecosystems (e.g. Colombini et al. 2003), this is to our knowledge the first account of the whole spectrum of macrobenthic fauna and marine flora inhabiting the supra-, medio- and upper infralittoral of shoreline strands from a long $(900 \mathrm{~km})$ NW Mediterranean stretch of coast. To achieve this result, various complementary methods were used. None of them alone would have helped collect the entire spectrum of organisms from the studied habitats.

The distance to the shoreline is the main factor driving the different habitats' structure (considered as macrofauna composition) in the strands. The macroinvertebrate assemblages at the supralittoral level were clearly different from those found at the medio- and infralittoral levels. This division between the supralittoral and the two other littoral levels has been observed in northern beaches of Spain (Rodil et al. 2006) and in Tunisia (Pérez-Domingo et al. 2008). Oligochaeta, Nematoda, and Turblellaria may be quantitatively dominant in several Mediterranean beach portions (see Covazzi Harriague et al. 2006) that are comparable to the supra- and mediolittoral levels studied here. Saccocirrus spp. and $P$. remota have been reported in coarse sediment of medio- and infralittoral beaches from other Mediterranean Sea areas (Villora-Moreno 1997, Covazzi Harriague and Albertelli 2007). The amphipods Monocorophium insidiosum and $C$. orientale, which were exclusively present in high numbers at sites 21 and 28, respectively, are used for toxicity testing and may prefer brackish waters (Prato et al. 2010). These two sites showed the highest infaunal richness. As regards the substrate types, the sediment classification (bottom type) was the second factor driving the difference in species composition. Fine sands showed distinctively different taxa from the rest of the sediments across the littoral levels. This pattern was even more evident when the supralittoral was excluded from the analyses, mainly because of the absence in fine-sand bottoms of Saccocirrus spp., P. remota, Hesionura serrata and Turbellaria, which were very common taxa in coarse sediments. The polychaete $H$. serrata, which is probably an alien species in the Mediterranean Sea (Zenetos et al. 2010), has been collected in medium to very coarse sediments in several areas of the NW Mediterranean (Authors, unpublished results). Fine-sand sites were inhabited by Nematoda and the polychaete S. mesnili, which reached 100 ind $\mathrm{m}^{-2}$ at the infralittoral level of site 26 (Estany Podrit), where it was dominant. $S$. mesnili is very common in fine-to-medium-sand bottoms in the lower infralittoral of the Mediterranean Sea (e.g. Pérez-Domingo et al. 2008). The cirolanid isopod 
E. affinis, which was captured only at fine-sand sites, is quite a common inhabitant of sandy beaches in the Mediterranean Sea (Dexter 1989, Munilla and San Vicente 2005). Finally, the bivalve D. trunculus was only observed in fine sediments (see also below) although its presence has been related to fine to medium sandy bottoms in the Mediterranean Sea (Pérez-Domingo et al. 2008, Weber and Zuschin 2013).

The qualitative samples collected with the clam nets and the spades were, overall, highly similar between the medio- and infralittoral levels. Clam nets proved to be irreplaceable tools for collecting the bivalve fauna from the medio- and infralittoral levels, particularly the species $D$. trunculus, D. semistriatus and E. minor, which were almost absent in the grab samples. The presence of some species in the qualitative samples was rather unexpected. The polychaete Perinereis sp., which may come from nearby rocky substrates, was not found again in subsequent samplings specifically targeting these organisms (Authors, unpublished research). Although we did not repeat the same samplings at the same site, the dominance of Nematoda, the Polychaeta Saccocirrus spp. and $P$. remota, Oligochaeta and Nemertea in the qualitative samples support the conclusion that these taxa are the most abundant in the shoreline strands studied. As expected, the compacted clays had a completely different flora and fauna. The bivalve Pholas dactylus, whose empty shells were copiously found in the immediate vicinity of the compacted clays, was absent in the qualitative samples. As in the case of the other bivalve species for which the collection of a large volume of sediment was needed for their detection, the spade sampling was possibly inadequate for the collection of this important boring mussel.

Traps (sticky and pitfall traps) collected a different array of organisms compared with the grabs at the supralittoral level, thus demonstrating their importance for properly describing species composition of beaches. Sticky traps were by far the most efficient devices for sampling animals moving over the sediment surface, such as insects. Epifauna abundance and richness in pitfall traps was much lower. Gauci et al. (2005) demonstrated the inefficiency of pitfall traps for capturing organisms on shingle beaches. Low animal abundance was also observed in Malta when pitfall traps were used (Deidun et al. 2003). The most frequent trap captures were Collembola (often representing more than $94 \%$ of the organisms at northern sites), Fucellia maritima and other diptera, as observed on other Mediterranean beaches (Colombini et al. 2005). On the other hand, the amphipod T. saltatorthe only abundant organism in the pitfall traps (Supplementary Material, Table S1) — was not as frequent and abundant as described in other studies (Węslawski et al. 2000, Pérez-Domingo et al. 2008, Reyes-Martínez et al. 2015). This species generally shows low densities in late winter, a rapid increase from early spring to July, and the highest densities in summer (Marques et al. 2003, Gonçalves et al. 2009). Thus, seasonality may be a major cause of the low densities recorded in this study. T. saltator is also known to move to terrestrial habitats and dunes in winter (Gonçalves et al. 2009).
With the obvious exceptions of sites 2 and 3, where the presence of $P$. oceanica wracks led to a distinct faunal composition (Gauci et al. 2005), our results show that there is no clear correspondence between any particular taxon and a specific supralittoral habitat based on substrate types. Most macroinvertebrates that move over supralittoral surfaces show no preference for any particular grain size. However, Collembola, which do not fly, seem to avoid fine sands, possibly because they provide them with no shelter for hiding. Once more, fine sands definitively prove to be different habitats at all the littoral levels studied.

Our results, based upon both epifauna and infauna, support the existence of key differences in the assemblages across the littoral levels and among bottom types. However, these differences were not observed when we focused on either epifauna or macroinfauna separately or on the results from a single sampling methodology. For instance, if we do not consider the infauna, the supralittoral level of unvegetated strands characterized by coarse sands, gravels and cobbles harbours a quite homogeneous assemblage, populated primarily by Collembola and some insect groups. Moreover, the medio- and upper infralittoral levels show very similar habitats, with Nematoda, Turbellaria, the polychaetes $P$. remota and Saccocirrus spp., the isopod $E$. affinis, and some bivalves as the principal taxa. However, strands characterized by fine sands are host to very distinct medio- and infralittoral assemblages mainly because of the presence of the bivalves Donax spp. and E. minor, which were exclusively collected with the clam net.

Richness may increase on protected sandy shores. By providing a greater surface for colonization, hides and crevices, particularly when cobbles are large or the exposure to water movements is small enough (see Sousa 1979), cobble shores may contain several algae and many macroinvertebrate species.

Variability in the biotic component among beaches has been attributed to a set of different factors in the literature. Shore characteristics such as the presence of vegetation, slope and coastal exposure, human pressures and food availability are among the main factors driving differences in species composition and abundance. Vegetation cover seems to favour high diversity of species because of the higher numbers of microhabitats available (Colombini et al. 2003). In this study, we have not dealt with vegetated strands, which cannot be considered as belonging to the strictly marine supralittoral level. Nevertheless, the proximity of Salicorniadominated salt marshes at site 28 may have played a role in determining the high numbers of observed taxa.

Gentle beach slopes, often accompanied by small grain sizes, on so-called dissipative beaches (low wave exposure) have often been related to higher abundance of species in other seas (see McLachlan 1996, McLachlan and Jaramillo 1995, Rodríguez et al. 2003). Here, despite the lack of strand slope and exposure assessments, the highest numbers of organisms and taxa were found at the more dissipative, gentle steeped sites regardless of the bottom type (i.e. sites 21 and 28). The cobble shore of site 21 (Delta del Foix) has extremely 
shallow waters, which protect the strand from the breaking waves (Authors, personal observations). The fine-sand shore at site 28 is confined into a shallow area in the largest bay of the Ebre Delta region.

Trampling and beach cleaning are among many human impacts that affect beaches worldwide (see Moffet et al. 1998, Gheskiere et al. 2005, Bessa et al. 2014). In the study area, mechanical beach cleaning and, especially, human trampling were very reduced or absent in autumn and winter months, when sampling was conducted. This may have helped reduce the potential effects of these activities on the results from the supralittoral and, to some extent, the mediolittoral levels. Site 28 , where trampling and cleaning never occur, showed the highest numbers of species and individuals (see Table 5 and Supplementary Material, Table S1). However, other sites, which are very frequented by people in summer (site 9) and where machine beach cleaning is performed, showed similar species abundance and richness (Table 5 and Supplementary Materia, Table S11). Daily and seasonal variability have also been claimed as important factors driving differences in richness and species abundance. However, such variability could not be observed in our study, since most sites were visited on one sampling date. This has been criticized by some authors (see Brazeiro and Defeo 1996). Nevertheless, results from so-called "snapshots" may reveal a shift of some taxa from one shore level to another rather than their complete disappearance (see Brazeiro and Defeo 1996). Moreover, much of the temporal difference has also been attributed to tidal migrations (see McLachlan and Jaramillo 1995), which are negligible because of the absence of tides in the study area. However, because of our winter-based sampling (see above), we ought to assume a bias in the estimations of the actual abundance for at least one species, $T$. saltator.

European environmental advisory programmes warn that conservation priorities need robust, widely accepted and affordable methods of habitat classification. In this study, we provide a clear assessment in this line, describing habitats in terms of features such as bottom type and the species that inhabit them. It seems that distance to the shoreline, particularly from the upper infralittoral to the mediolittoral level, and the bottom type features are only to a certain extent valid predictors of the presence of specific biotic components. Thus, general habitat divisions based upon littoral level and grain size ought to be accepted with caution. Finally, we provide a comparison between the most used classification schemes (EUNIS, CORINE Biotopes and LPRE nomenclatures; see Appendix 1), which we believe is especially valuable for managing practices.

\section{ACKNOWLEDGEMENTS}

We would like to thank the rangers and managers of the Cap de Creus Natural Park, Delta de l'Ebre Natural Park, and the Consorci per a la Potecció i Gestió dels Espais Naturals del Delta del Llobregat. Esther Jordana, João Gil, Maria Paola Satta and Maria Paola Mura kindly helped with the identification of polychaetes and peracarids. Financial support came from the projects "Cartografia dels Hàbitats Litorals a Catalunya" (Departament de Territori i Sosteniblitat and Institut Cartogràfic, Generalitat de Catalunya) and INTRAMURAL CSIC 201330E065.

\section{REFERENCES}

Ballesteros E., Mariani S., Cefalì M.E., et al. 2014. Manual dels hàbitats litorals de Catalunya. Generalitat de Catalunya. Departament de Territori i Sostenibilitat. $251 \mathrm{pp}$.

Bessa F., Cunha D., Gonçalves S.C., et al. 2013. Sandy beach macrofaunal assemblages as indicators of anthropogenic impacts on coastal dunes. Ecol. Indic. 30: 196-204. https://doi.org/10.1016/j.ecolind.2013.02.022

Bessa F., Gonçalves S.C., Franco J.N., et al. 2014. Temporal changes in macrofauna as response indicator to potential human pressures on sandy beaches. Ecol. Indi. 41: 49-57. https://doi.org/10.1016/j.ecolind.2014.01.023

Brazeiro A., Defeo O. 1996. Macroinfauna zonation in microtidal sandy beaches: is it possible to identify patterns in such variable environments? Estuar. Coast. Shelf Sci. 42: 523-536. https://doi.org/10.1006/ecss.1996.0033

Chappuis E., Terradas M., Cefalì M.E., et al. 2014. Vertical zonation is the main distribution pattern of littoral assemblages on rocky shores at a regional scale. Estuar. Coast. Shelf Sci. 147: 113-122. https://doi.org/10.1016/j.ecss.2014.05.031

Colombini I., Fallaci M., Milanesi F., et al. 2003. Comparative diversity analysis in sandy litoral ecosystems of the western Mediterranean. Estuar. Coast. Shelf Sci. 58: 93-104. https://doi.org/10.1016/S0272-7714(03)00035-0

Colombini I., Bouslama M.F., Elgtari M. 2005. Study of the community structure of terrestrial arthropods of a Mediterranean sandy beach ecosystem of Morocco. In: Bayed A., Scapini F. (eds), Ecosystèmes côtiers sensibles de la Méditerranée: cas du littoral de Smir. Travaux de l'Institut Scientifique, Rabat, série general 4: 43-54.

Covazzi Harriague A., Albertelli G. 2007. Environmental factors controlling macrofaunal assemblages on six microtidal beaches of the Ligurian Sea (NW Mediterranean). Estuar. Coast. Shelf Sci. 73: 8-16. https://doi.org/10.1016/j.ecss.2006.12.007

Covazzi Harrigaue A., Gaozza L., Montella A., et al. 2006. Benthic communities on a sandy Ligurian beach (NW Mediterranean). Hydrobiologia 571: 383-394. https://doi.org/10.1007/s10750-006-0264-3

Dahl E. 1952. Some aspects of the ecology and zonation of the fauna on sandy beaches. Oikos 4: 1-25. https://doi.org/10.2307/3565072

Deidun A., Azzopardi M., Saliba S., et al. 2003. Low faunal diversity on Maltese sandy beaches: fact or artefact? Estuar. Coast. Shelf Sci. 58: 83-92. https://doi.org/10.1016/S0272-7714(03)00036-2

Dexter D.M. 1989. The sandy beach fauna of Egypt. Estuar. Coast. Shelf Sci. 29: 261-271. https://doi.org/10.1016/0272-7714(89)90057-7

Fraschetti S., Terlizzi A., Benedetti-Cecchi L. 2005. Patterns of distribution of marine assemblages from rocky shores: evidence of relevant scales of variation. Mar. Ecol. Prog. Ser. 296: 13-29. https://doi.org/10.3354/meps296013

Gauci M.J., Deidun A., Schembri P.J. 2005. Faunistic diversity of Maltese pocket sandy and shingle beaches: are these of conservation value? Oceanologia 47: 219-241.

Gheskiere T., Vincx M., Weslawski J.M., et al. 2005. Meiofauna as descriptor of tourism-induced changes at sandy beaches. Mar. Environ. Res. 60: 245-265. https://doi.org/10.1016/j.marenvres.2004.10.006

Gonçalves S.C. Anastácio P.M., Pardal M.A., et al. 2009. Sandy beach macrofaunal communities on the western coast of Portugal - Is there a steady structure under similar exposed conditions? Estuar. Coast. Shelf Sci. 81: 555-568. https://doi.org/10.1016/j.ecss.2008.12.004

Janssen G., Mulder S. 2005. Zonation of macrofauna across sandy beaches and surf zones along the Dutch coast. Oceanologia 47: 265-282.

Labrune C., Grémare A., Amouroux J.M., et al. 2007. Assessment of soft-bottom polychaete assemblages in the Gulf of Lions 
(NW Mediterranean) based on a mesoscale survey. Estuar. Coast. Shelf Sci. 71: 133-147.

https://doi.org/10.1016/j.ecss.2006.07.007

Marques J.C., Gonçalves S.C., Pardal M.A., et al. 2003. Comparison of Talitrus saltator (Amphipoda, Talitridae) biology, dynamics, and secondary production in Atlantic (Portugal) and Mediterranean (Italy and Tunisia) populations. Estuar. Coast. Shelf Sci. 58: $127-148$. https://doi.org/10.1016/S0272-7714(03)00042-8

McLachlan A. 1983. The ecology of sandy beaches in the Eastern Cape, South Africa. In: McLachlan A., Erasmus T. (eds), Sandy beaches as ecosystems. The Hague, Junk, pp. 321-380.

McLachlan A. 1996. Physical factors in benthic ecology: effects of changing sand particle size on beach fauna. Mar. Ecol. Prog. Ser. 131: 205-217. https://doi.org/10.3354/meps 131205

McLachlan A., Brown A.C. 2006. The Ecology of Sandy Shores. Academic Press, Burlington, MA, USA. 373 pp.

McLachlan A., Jaramillo E. 1995. Zonation on sandy beaches. Oceanogr. Mar. Biol. 33: 305-335.

Menge B.A., Lubchenco J., Ashkenas L.R. 1985. Diversity, heterogeneity, and consumer pressure in a tropical rocky intertidal community. Oecologia 65: 394-405. https://doi.org/10.1007/BF00378915

Moffet M.D., McLachlan A., Winter P.E.D., et al. 1998. Impact of trampling on sandy beach macrofauna. J. Coast. Conservat. 4: 87-90. https://doi.org/10.1007/BF02806494

Munilla T., San Vicente C. 2005. Suprabenthic biodiversity of Catalan beaches (NW Mediterranean). Acta Oecol. 27: 81-91. https://doi.org/10.1016/j.actao.2004.09.006

Munilla T., Corrales M.J., San Vicente C. 1998. Suprabenthic assemblages from Catalan beaches: zoological groups. Orsis 13: 67-78.

Pérez-Domingo S., Castellanos C., Junoy J. 2008. The sandy beach macrofauna of Gulf of Gabès (Tunisia). Mar. Ecol. 29: 51-59. https://doi.org/10.1111/j.1439-0485.2007.00201.x

Pinedo S., Sardá R., Martin D. 1997. Comparative study of the trophic structure of soft-bottom assemblages in the Bay of Blanes (Western Mediterranean Sea). Bull. Mar. Sci. 60: 529-542.

Prato E., Bigongiari N., Barghigiani C., et al. 2010. Comparison of amphipods Corophium insidiosum and $C$. orientale (Crustacea: Amphipoda) in sediment toxicity testing. J. Environ. Sci. Health A 45: 1461-1467. https://doi.org/10.1080/10934529.2010.500941

Reyes-Martínez M.J., Ruiz-Delgado M.C., Sánchez-Moyano J.E., et al. 2015. Biodiversity and distribution of macroinfauna assemblages on sandy beaches along the Gulf of Cádiz (SW Spain). Sci. Mar. 79: 367-377. https://doi.org/10.3989/scimar.04133.30A

Rodil I.F., Lastra M., Sánchez-Mata A.G. 2006. Community structure and intertidal zonation of the macroinfauna in intermediate sandy beaches in temperate latitudes: North coast of Spain. Estuar. Coast. Shelf Sci. 67: 267-279. https://doi.org/10.1016/j.ecss.2005.11.018

Rodil I.F., Compton T.J., Lastra M. 2014. Geographic variation in sandy beach macrofauna community and functional traits. Estuar. Coast. Shelf Sci. 150: 10-110. https://doi.org/10.1016/j.ecss.2013.06.019
Rodríguez J.G., Lastra M., López J. 2003. Meiofauna distribution along a gradient of sandy beaches in northern Spain. Estuar. Coast. Shelf Sci. 58: 63-69. https://doi.org/10.1016/S0272-7714(03)00039-8

Sardá R., Pinedo S., Martin D. 1999. Seasonal dynamics of macrofaunal key species inhabiting shallow soft-bottoms in the Bay of Blanes (NW MEditerranean). Acta Oecol. 20: 315-326. https://doi.org/10.1016/S1146-609X(99)00135-6

Schlacher T.A., Thompson L. 2013. Spatial structure on oceanexposed sandy beaches: faunal zonation metrics and their variability. Mar. Ecol. Prog. Ser. 478: 43-55. https://doi.org/10.3354/meps 10205

Sousa W.P. 1979. Disturbance in marine intertidal boulder fields: the nonequilibrium maintenance of species diversity. Ecology 60: $1225-1239$ https://doi.org/10.2307/1936969

Stotz W.B., Aburto J., Caillaux L.M., et al. 2016. Vertical distribution of rocky subtidal assemblages along the exposed coast of north-central Chile. J. Sea Res. 107: 34-47. https://doi.org/10.1016/j.seares.2015.11.006

Templado J., Ballesteros E., Galparsoro I., et al. 2012. Inventario Español de Hábitats y Especies Marinos. Ministerio de Agricultura, Alimentación y Medio Ambiente. Gobierno de España, Madrid. 229 pp.

Underwood A.J., Denley E.J. 1984. Paradigms, explanations, and generalizations in models for the structure of intertidal communities on rocky shores. In: Strong D.R., Simberloff D., et al. (eds), Ecological communities: conceptual issues and the evidence. Princeton University Press, Princeton, New Jersey. pp. 151-180. https://doi.org/10.1515/9781400857081.151

Villora-Moreno S. 1997. Environmental heterogeneity and the biodiversity of interstitial polychaeta. Bull. Mar. Sci. 60: 494-501.

Weber K., Zuschin M. 2013. Delta-associated molluscan life and death assemblages in the northern Adriatic Sea: Implications for paleoecology, regional diversity and conservation. Palaeogeogr. Palaeoclimatol. Palaeoecol. 370: 77-91. https://doi.org/10.1016/j.palaeo.2012.11.021

Węslawski J.M., Kupidura T., Źabicki M. 2000. Sandhoppers, Talitrus saltator (Montagu, 1808) (Amphipoda, Gammaridea), at the Polish Baltic coast: seasonal and spatial distribution patterns. Crustaceana 73: 961-969. https://doi.org/10.1163/156854000505010

Zenetos A., Gofas S., Verlaque M., et al. 2010. Alien species in the Mediterranean areas of the European Union's Marine Strategy Framework Directive (MFSD) by 2010. Part I. Spatial distribution. Mediterr. Mar. Sci. 11: 381-493.

\section{SUPPLEMENTARY MATERIAL}

The following supplementary material is available through the online version of this article and at the following link:

http://scimar.icm.csic.es/scimar/supplm/sm4445esm.xlsx

Table S1. - A, total abundance values for grabs and traps (ind. $\mathrm{m}^{-2}$ and ind. $\mathrm{h}^{-1}$ trap $^{-1}$, respectively); and $\mathrm{B}$, total abundance values for qualitative samples (ind. sample ${ }^{-1}$ ). 


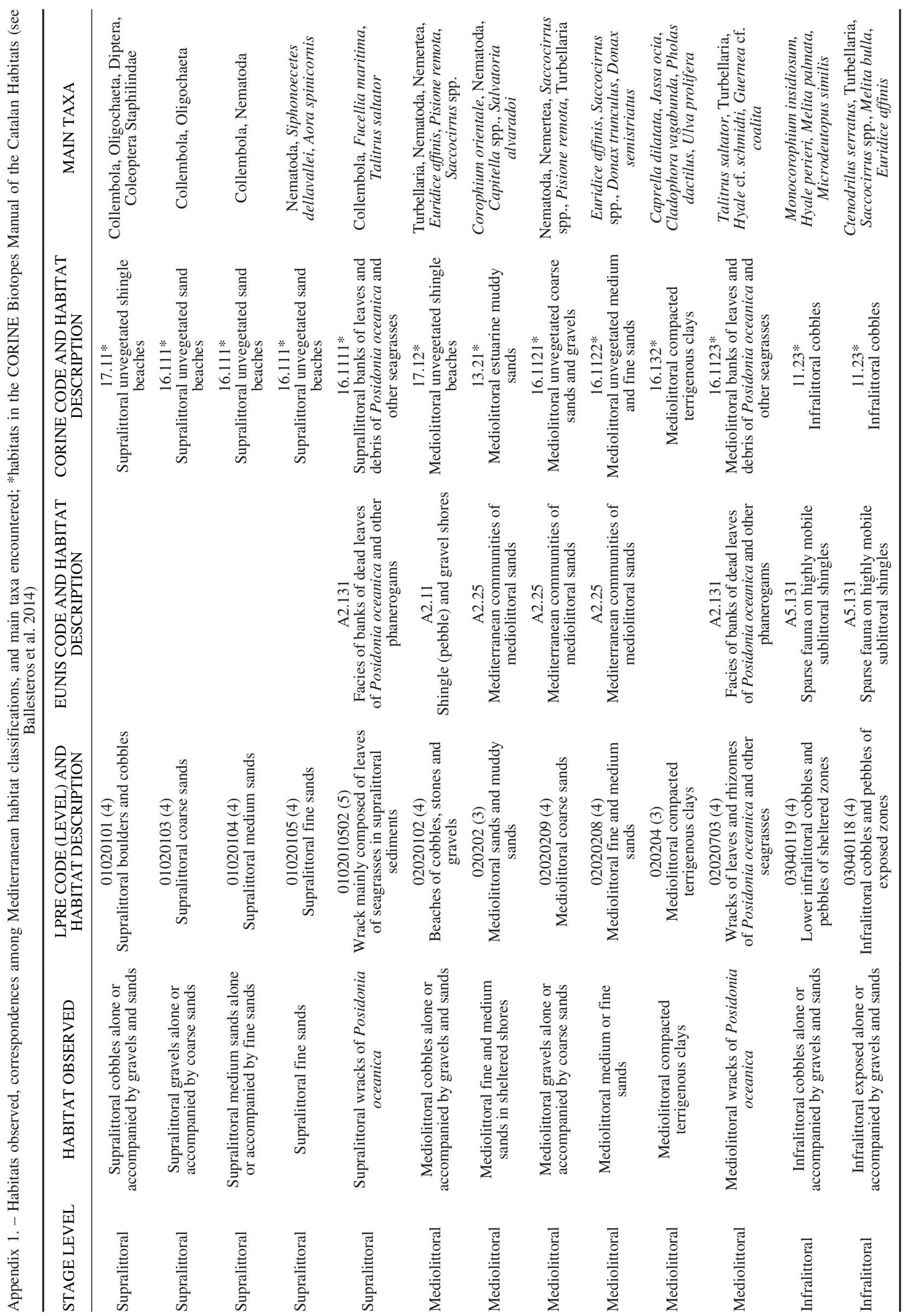


282 - S. Mariani et al.

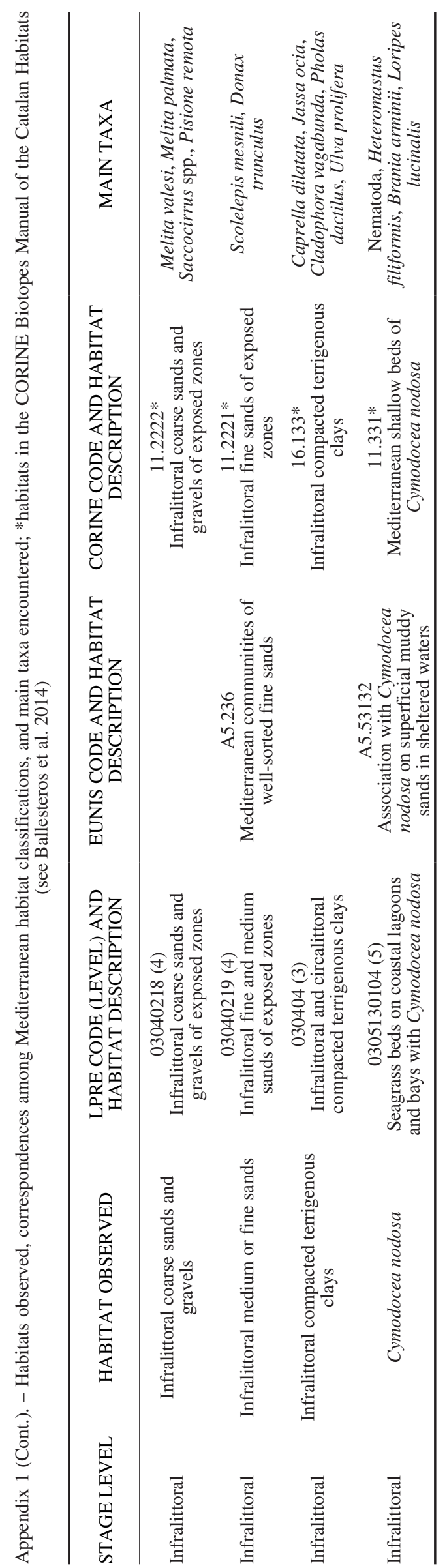

